\title{
Extractive Spectrophotometric Determination of Tenofovir Disoproxil Fumarate Using Acidic Triphenylmethane Dyes
}

\author{
K. Susmitha, ${ }^{1}$ M. Thirumalachary, ${ }^{1}$ T. Charan Singh, ${ }^{2}$ and G. Venkateshwarlu ${ }^{3}$ \\ ${ }^{1}$ Department of Chemistry, Jawaharlal Nehru Technology University, Hyderabad 500085, India \\ ${ }^{2}$ G.Narayanamma Institute of Technology \& Science, Hyderabad 500008, India \\ ${ }^{3}$ Department of Chemistry, Nizam College (O.U.), Hyderabad, Andhra Pradesh 500001, India
}

Correspondence should be addressed to G. Venkateshwarlu; venkateshwarlugoud@yahoo.com

Received 13 December 2013; Accepted 5 February 2014; Published 12 March 2014

Academic Editors: R. Fausto and P.-C. Liao

Copyright (C) $2014 \mathrm{~K}$. Susmitha et al. This is an open access article distributed under the Creative Commons Attribution License, which permits unrestricted use, distribution, and reproduction in any medium, provided the original work is properly cited.

\begin{abstract}
Tenofovir disoproxil fumarate is a nucleotide reverse transcriptase inhibitor that has activity against the hepatitis B and HIV viruses. Three simple and sensitive extractive spectrophotometric methods have been described for the assay of tenofovir disoproxil fumarate either in pure form or in pharmaceutical formulations. The developed methods involve formation of colored chloroform extractable ion-pair complexes of the drugs with triphenylmethane dyes, namely, bromothymol blue (BTB), bromophenol blue (BPB), and bromocresol purple (BCP) in acidic medium. The extracted complexes showed absorbance maxima between 410 and $415 \mathrm{~nm}$. Beer's law is obeyed in the concentration ranges $1.5-25,1.0-25$, and $1.25-25 \mu \mathrm{g} \mathrm{mL}^{-1}$ with BTB, BPB, and BCP, respectively. The effectc of concentration of dye, $\mathrm{pH}$, and interference of excipients have been studied and optimized. The limits of detection and quantification have been determined. All three methods are validated as per the guidelines of ICH. The methods have been applied to the determination of drug in commercial tablets and results of analysis were validated statistically through recovery studies.
\end{abstract}

\section{Introduction}

Tenofovir disoproxil fumarate (TDF) 9-[(R)-2-[[bis[(isopropoxycarbonyl)oxy]methoxy]phosphinyl]methoxy]propyl] adenine fumarate is antiviral agent acts as nucleoside reverse transcriptase enzyme inhibitor [1]. It is a nucleoside analogue which is phosphorylated by host cell enzyme to give 5-triphosphate derivative. This moiety competes with the equivalent host cellular triphosphate for proviral DNA synthesis by viral reverse transcriptase which is viral RNA-dependent DNA polymerase. Incorporation of the 5 -triphosphate moiety into the growing viral DNA chain results in chain termination. It is indicated in combination with other antiretroviral agents for the treatment of HIV-1 infection in adults $[2,3]$.

The literature survey revealed that only few methods are available for the determination of tenofovir in dosage forms and include liquid chromatography with tandem mass spectrometry $[4,5]$; HPLC with solid phase extraction [6]; reversed phase HPLC $[7,8]$; HPLC with spectrophotometric detection [9]; HPTLC [10]; gradient ion-pair LC with fluorescent detector [11]; and HPLC-UV, HPLC-MS [12], and first-order UV derivative spectrophotometry [13, 14]. Visible spectrophotometry, because of its simplicity, costeffectiveness, sensitivity, selectivity, fair accuracy, and precision, has remained competitive in pharmaceutical analysis. In a method described by Onah and Ajima, tenofovir [15] was quantified by complexation with ammonium molybdatestannous chloride having maximum absorption at $495 \mathrm{~nm}$, and, with picric acid, it forms blue coloured complex that is absorbed maximally at $465 \mathrm{~nm}$.

Because of its physiological significance, the quantitative determination of tenofovir attracted the attention of analytical chemists and almost all analytical methods have been applied to accomplish the purpose. However, methods based on spectrophotometric determination of this drug involving ion-pair complexes with common and versatile acidic dyes namely, bromothymol blue (BTB), bromocresol purple (BCP), and bromophenol blue (BPB) are not reported yet. This prompted the authors to develop extractive spectrophotometric methods for the determination of tenofovir using the above mentioned dyes. 


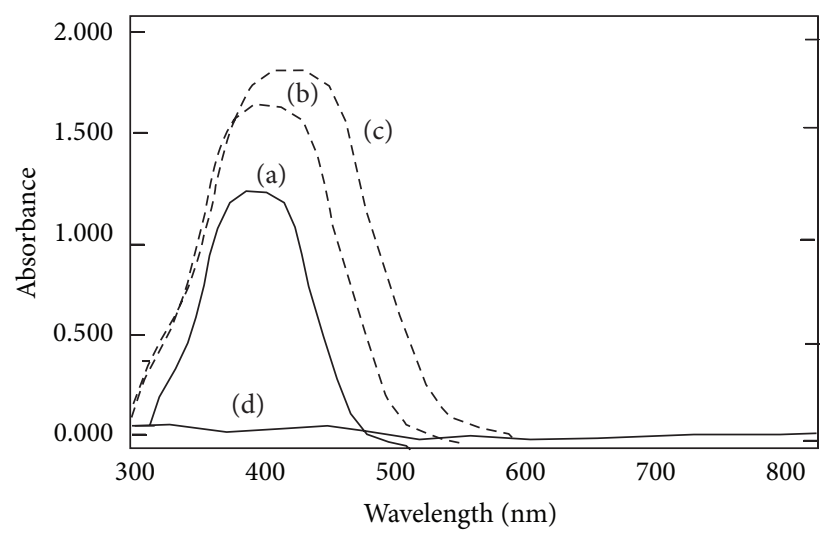

FIGURE 1: Absorption spectra of tenofovir disoproxil fumarate-dye complex extracted into $10 \mathrm{~mL}$ chloroform: (a) drug $=20 \mu \mathrm{g} \mathrm{mL} \mathrm{m}^{-1}+5 \mathrm{~mL}$ of $0.025 \%$ BTB $+5 \mathrm{~mL}$ of pH 2.8 buffer; (b) drug $=25 \mu \mathrm{g} \mathrm{mL} \mathrm{L}^{-1}+5 \mathrm{~mL}$ of $0.025 \% \mathrm{BPB}+5 \mathrm{~mL}$ of pH 2.5 buffer; (c) drug $=25 \mu \mathrm{g} \mathrm{mL}+5 \mathrm{~mL}^{-1}$ of $0.025 \% \mathrm{BCP}+5 \mathrm{~mL}$ of $\mathrm{pH} 2.5$ buffer; and (d) drug $=0 \mu \mathrm{g} \mathrm{mL} \mathrm{m}^{-1}+5 \mathrm{~mL}$ of $0.025 \%$ dye $+5 \mathrm{~mL}$ of buffer.

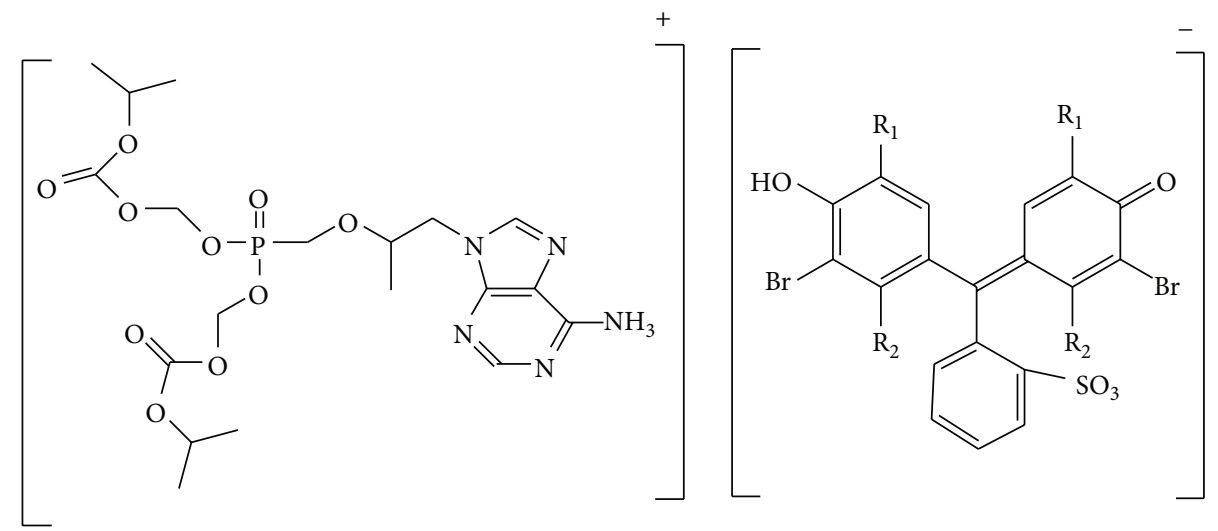

Scheme 1: Tenofovir disoproxil fumarate-dye complex. Bromothymol blue: $\mathrm{R}_{1}=$ isopropyl, $\mathrm{R}_{2}={ }^{\circ} \mathrm{CH}_{3}$. Bromophenol blue: $\mathrm{R}_{1}=\mathrm{Br}, \mathrm{R}_{2}=\mathrm{H}$. Bromocresol purple: $\mathrm{R}_{1}={ }^{\cdot} \mathrm{CH}_{3}, \mathrm{R}_{2}=\mathrm{H}$.

In this paper, we report three simple and sensitive extractive spectrophotometric methods for the assay of tenofovir. The methods are based on ion-pair complexation of drug with dyestuffs such as BTB, BCP, and BPB and subsequent extraction into chloroform and to measure the absorbance of colour complex. The proposed methods have the advantages of speed and simplicity besides being accurate and precise and can be adopted by the pharmaceutical laboratories for industrial quantitative analysis.

\section{Experimental}

2.1. Materials and Methods. Tenofovir disoproxil fumarate (TDF) is procured from Aurobindo Pharmaceuticals, Hyderabad, as a gift sample. The dyestuffs, namely, BTB, BPB, and BCP (AR grade) supplied by SD Fine Chemicals Ltd., Mumbai, are used without any further purification. The dyestuffs were used as $0.025 \%$ solutions in doubly distilled water.

Sodium acetate-hydrochloric acid buffers of $\mathrm{pH} 2.5$ for $\mathrm{BPB}$ and $\mathrm{BCP}$ and 2.8 for BTB were prepared by mixing $50 \mathrm{~mL}$ of $1.0 \mathrm{M}$ sodium acetate solution with $50.50,49.50$, respectively, of $1.0 \mathrm{M} \mathrm{HCl}$ solution and diluted to $250 \mathrm{~mL}$ with doubly distilled water. The $\mathrm{pH}$ of each solution was adjusted to an appropriate value with the aid of a $\mathrm{pH}$ meter. Chloroform (HPLC grade) supplied by SD Fine Chemicals Ltd., Mumbai, is used throughout the work. Stock solutions were prepared for all the dyes and drug $(25 \mathrm{mg} / 100 \mathrm{~mL})$.

The spectra (Figure 1) of ion-pair complexes have been recorded on SHIMADZU 140 double beam spectrophotometer, Thermo Nicolet 1000, and also on ELICO 159 UV-Visible single beam spectrophotometer using quartz cells of $10 \mathrm{~mm}$ path length. An Elico model Li-120 pH meter was used for $\mathrm{pH}$ measurement.

\section{Results and Discussion}

TDF forms ion-pair complexes in acidic buffer with dyestuffs, namely, bromothymol blue (BTB), bromophenol blue (BPB), and bromocresol purple (BCP), and these complexes are quantitatively extracted into chloroform. Ion-pair complexes of drug with BTB, BPB, and BCP are absorbed maximally between 410 and $415 \mathrm{~nm}$. The reagent blank under similar conditions showed no absorption. 
TABLE 1: Spectral and analytical parameters for the determination of TDF with triphenylmethane dyes.

\begin{tabular}{lccc}
\hline Parameters & BTB & BPB & BCP \\
\hline$\lambda \max (\mathrm{nm})$ & 412 & 412 & 413 \\
Beer's law limits $\left(\mu \mathrm{g} \mathrm{mL}^{-1}\right)$ & $4.0-40$ & $4.0-40$ & $4.0-40$ \\
Molar absorptivity $\left(\mathrm{L} \mathrm{Mol}^{-1} \mathrm{~cm}^{-1}\right)$ & 7462 & 5084 & 5289 \\
Formation constant $\left({\left.\mathrm{K}, ~ \mathrm{M}^{-1}\right)}^{-2}\right)$ & $1.342 \times 10^{6}$ & $1.256 \times 10^{6}$ & $1.42 \times 10^{6}$ \\
Sandell's sensitivity $\left(\mu \mathrm{g} \mathrm{cm}^{6}\right)$ & 0.0549 & 0.0806 & 0.077 \\
Slope $(a)$ & 0.0182 & 0.0124 & 0.0129 \\
Intercept $(b)$ & 0.0499 & 0.0842 & 0.1168 \\
Correlation coefficient $(r)$ & 0.998 & 0.999 & 0.998 \\
Limit of detection $\left(\mu \mathrm{g} \mathrm{mL} \mathrm{mL}^{-1}\right)$ & 0.44 & 0.44 & 0.44 \\
Limit of quantification $(\mu \mathrm{g} \mathrm{mL}$ & 1.3 & 1.3 \\
Regression equation $Y=b+a x$ & 1.3 & $Y=0.0842+0.0124 x$ & $Y=0.1168+0.013 x$ \\
\hline
\end{tabular}

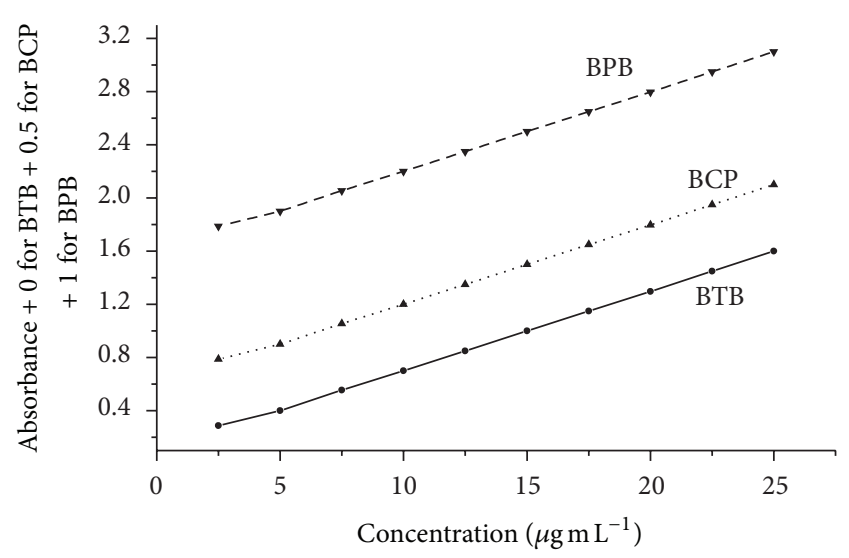

FIGURE 2: Calibration curves for TDF-dye ion-pair complex.

Tenofovir disoproxil fumarate undergoes protonation of adenine ring in acidic medium, while sulphonic acid group is present in $\mathrm{BTB}, \mathrm{BPB}$, and $\mathrm{BCP}$ that is the only group undergoing dissociation in the $\mathrm{pH}$ range 1-5. The color of such dyes is due to the opening of lactoid ring and subsequent formation of quinoid group. It is supposed that the two tautomers are present in equilibrium, but, due to strong acidic nature of the sulphonic acid group, the quinoid body must predominate. Finally, the protonated TDF forms ion-pairs with the dyestuffs which are quantitatively extracted into chloroform. The drug-dye ion-pair complex behaves as a single unit held together by an electrostatic force of attraction as shown in Scheme 1.

3.1. Calibration Curves. Different aliquots of drug solution were transferred into $125 \mathrm{~mL}$ separating funnel. To this $5 \mathrm{~mL}$

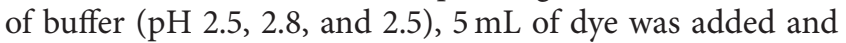
total volume was made up to $20 \mathrm{~mL}$ with water. $10 \mathrm{~mL}$ of chloroform was added and the contents were shaken for $5 \mathrm{~min}$. The two layers were allowed to separate for $5 \mathrm{~min}$. The organic layer was separated and absorbance of yellow colored solution which is stable at least for $3 \mathrm{hrs}$ is measured between 410 and $415 \mathrm{~nm}$ against blank similarly prepared.
TAble 2: Precision and accuracy studies of the different methods developed for the assay of TDF.

\begin{tabular}{lccc}
\hline & BTB & BPB & BCP \\
\hline Amount taken & 6 & 6 & 6 \\
$\left(\mu \mathrm{g} \mathrm{mL}^{-1}\right)$ & 10 & 10 & 10 \\
& 14 & 14 & 14 \\
& 18 & 18 & 18 \\
\hline Amount found & 6 & 6 & 6.027 \\
$\left(\mu \mathrm{g} \mathrm{mL}^{-1}\right)$ & 9.97 & 9.97 & 10.016 \\
& 14.01 & 14.03 & 14.01 \\
& 18.01 & 17.97 & 17.95 \\
\hline Recovery \% & 100 & 100 & 100.46 \\
& 99.73 & 99.78 & 100.16 \\
\hline RSD \% & 100.07 & 100.26 & 100.013 \\
Mean \pm SD & 100.07 & 99.87 & 99.7 \\
\hline Reference $[14]$ & 0.16 & 0.218 & 0.31 \\
Mean \pm SD & $99.98 \pm 0.16$ & $100.01 \pm 0.22$ & $100.08 \pm 0.3$ \\
\hline$t$-test & $100.8 \pm 1.09$ & $100.8 \pm 1.09$ & $100.8 \pm 1.09$ \\
$F$-test & 1.64 & 1.58 & 1.39 \\
\hline
\end{tabular}

The same procedure of analysis is followed either for assay of pure drug or for dosage form. The calibration graphs (Figure 2) that are linear over the concentration ranges are within the permissible range. The optical characteristics and statistical data for the regression equation of the proposed methods are presented in Table 1.

3.2. Procedure for the Assay of Pure Drug. Four different solutions of pure drug in the range of calibration curve were selected and the recovery experiments were performed. The recoveries and their relative standard deviations are tabulated in Table 2 for five replicates.

3.3. Procedure for the Assay of Dosage Forms. 2 Tablets of VIREAD $150 \mathrm{mg}$ are powdered and dissolved in doubly 
TABLE 3: Application of proposed method for the analysis of the TDF in pharmaceutical forms.

\begin{tabular}{lccc}
\hline $\begin{array}{l}\text { VIREAD } \\
150 \mathrm{mg} / \mathrm{Tab} .\end{array}$ & $\mathrm{BTB}$ & $\mathrm{BPB}$ & $\mathrm{BCP}$ \\
\hline & 3.5 & 3.5 & 3.5 \\
Amount taken & 6.5 & 6.5 & 6.5 \\
$\left(\mu \mathrm{g} \mathrm{mL}^{-1}\right)$ & 9.5 & 9.5 & 9.5 \\
& 12.5 & 12.5 & 12.5 \\
\hline & 3.477 & 3.48 & 3.48 \\
Amount found & 6.476 & 6.52 & 6.51 \\
$\left(\mu \mathrm{g} \mathrm{mL}^{-1}\right)$ & 9.51 & 9.6 & 9.47 \\
& 12.55 & 12.45 & 12.49 \\
\hline & 99.37 & 99.48 & 99.37 \\
Recovery \% & 99.63 & 100.26 & 100.25 \\
& 100.11 & 100.93 & 99.72 \\
& 100.39 & 99.63 & 99.93 \\
\hline RSD \% & 0.464 & 0.66 & 0.3675 \\
Mean \pm SD & $99.88 \pm 0.46$ & $100.076 \pm 0.66$ & $99.82 \pm 0.367$ \\
\hline Reference $[14]$ & $100.8 \pm 1.09$ & $100.8 \pm 1.09$ & $100.8 \pm 1.09$ \\
Mean \pm SD & 1 & 0.39 & 0.4987 \\
\hline -test & & 1.759 & 1.256 \\
$F$-test & 0.859 & &
\end{tabular}

distilled water, stirred thoroughly, and filtered through a Whatman number 42 filter paper. This solution was transferred into $100 \mathrm{~mL}$ standard volumetric flask and diluted with doubly distilled water as required. Different solutions of drug in the range of calibration curve were chosen and the assay was estimated using the calibration curve. The results of the recovery experiments are tabulated in Table 3 .

In order to establish molar ratio between TDF and dyestuffs used, the Job's method of continuous variation [16, 17] has been applied. In this method, solutions of drug and dyestuff with identical molar concentrations $\left(8 \times 10^{-5} \mathrm{M}\right)$ were mixed in varying volume ratios in such a way that the total volume of each mixture was the same. The absorbance of each solution was measured and plotted against the mole fraction of the drug, (drug)/(drug) + (dyestuff) (Figure 3). This measurement showed that $1: 1$ complex was formed with each dyestuff. The formation constants $[18,19]$ were also estimated and found to be $1.342 \times 10^{6}, 1.256 \times 10^{6}$, and $1.425 \times$ $10^{6} \mathrm{M}^{-1}$ for complexes with BTB, BPB, and BCP, respectively.

The influence of $\mathrm{pH}$ on the ion-pair formation of Tenofovir disoproxil fumarate with various dyestuffs has been studied using sodium acetate-hydrochloric acid buffer. The results are shown in Figure 4. It is evident that absorbance of complexes with $\mathrm{BTB}, \mathrm{BPB}$, and $\mathrm{BCP}$ was found to be constant within the $\mathrm{pH}$ ranges 2.2-3.3 (BTB), 2.0-3.0 (BPB, $\mathrm{BCP})$, respectively. Thus, all the absorbance measurements were made at $\mathrm{pH} 2.8,2.5$, and 2.5 with $\mathrm{BTB}, \mathrm{BPB}$, and $\mathrm{BCP}$, respectively.

The effect of dyestuff concentrations was also studied by adding different volumes of dyestuff to a constant amount of $\operatorname{TDF}\left(15.0 \mu \mathrm{g} \mathrm{mL}^{-1}\right)$. It is apparent from Figure 5 that

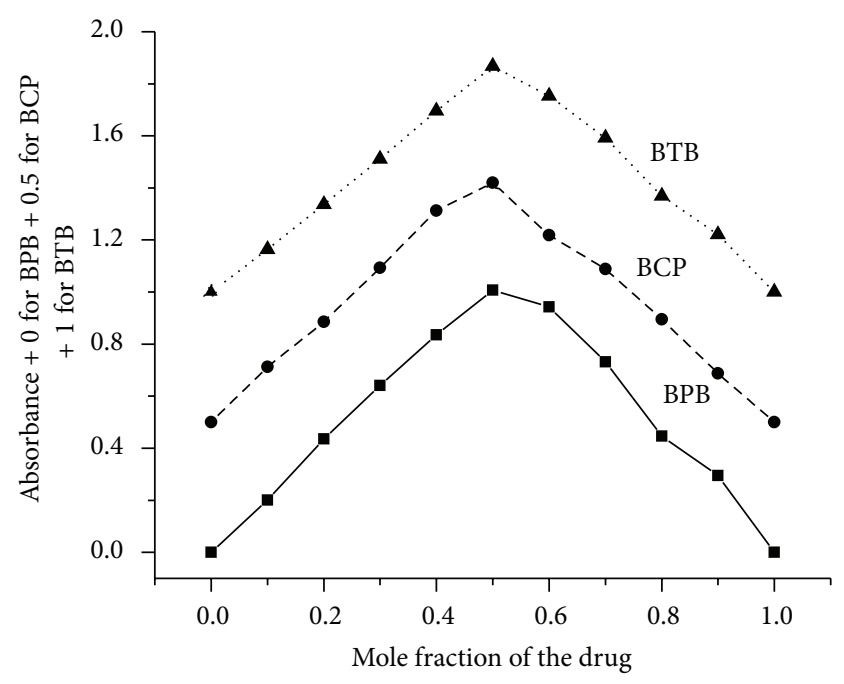

FIGURE 3: Continuous variation study of drug-dye system. (Drug) + $($ Dye $)=8.00 \times 10^{-5} \mathrm{M}$.

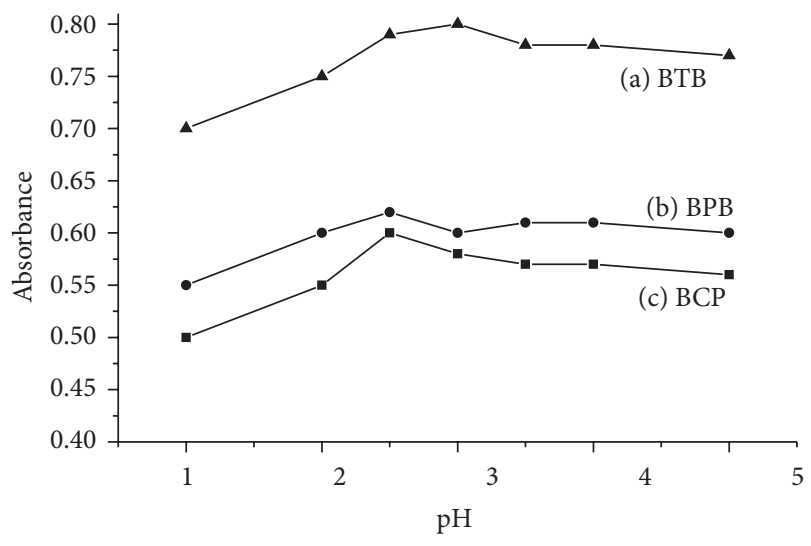

FIGURE 4: Effect of $\mathrm{pH}($ Drug $)=15 \mu \mathrm{g} \mathrm{mL}^{-1}$, (Dye) $=5 \mathrm{~mL}$ of $0.025 \%$.

the maximum absorbance in each case was found with $2.0 \mathrm{~mL}$ of dyestuff, beyond which absorbance was constant. Thus, $5 \mathrm{~mL}$ of each dyestuff was used for ion-pair formation throughout the experiment.

A systematic study of the effect of foreign species present along with TDF at $15.0 \mu \mathrm{g} \mathrm{mL}^{-1}$ levels was undertaken. This study was carried out by following the proposed procedures for a $10 \mathrm{~mL}$ sample system, by adding a known amount of foreign species to TDF solution of $15.0 \mu \mathrm{g} \mathrm{mL}^{-1}$ summarizes the results obtained. However, the drug content from the powdered tablets was extracted into chloroform, which completely removes any interference by the common excipients found in formulations.

\section{Validation of the Proposed Methods}

All the three proposed methods have been validated in terms of guideline proposed by ICH [20], namely, selectivity, specificity, accuracy, precision, limits of calibration curve, LOD, LOQ, robustness, ruggedness, and regression equation. 


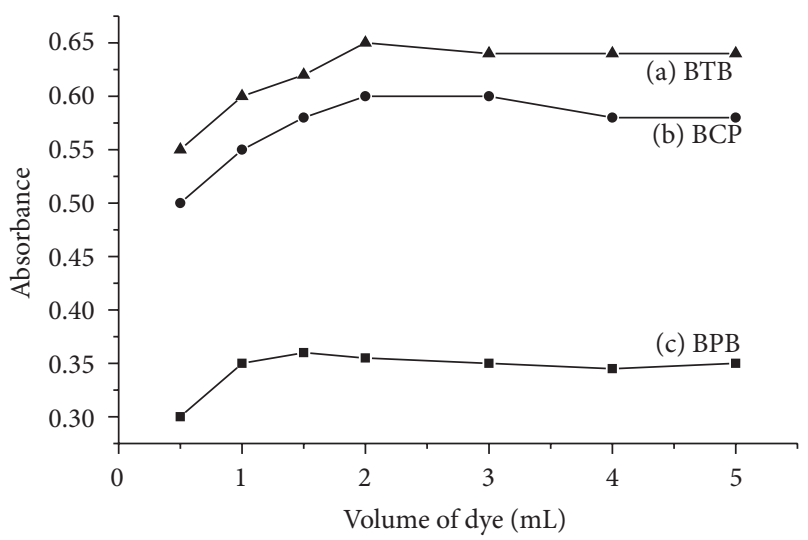

Figure 5: Influence of volume of $0.025 \%$ Dye (Drug) $=15 \mu \mathrm{g} \mathrm{mL}^{-1}$.

The student $t$-test and variance $F$-test have been performed in comparison with a reference method. (Table 1) summarizes the values for Beer's law limits, molar absorptivity, regression equation, correlation coefficients, relative standard deviation, and recoveries. To test the reproducibility of the proposed methods, six replicate determinations of $15 \mu \mathrm{g} \mathrm{mL}^{-1}$ of studied TDF are made. The coefficient of variation was found to be less than $1.0 \%$ for all the procedures.

The proposed methods have been successfully applied to the determination of TDF in pharmaceutical preparations. The performance order of the proposed methods is BCP > $\mathrm{BTB}>\mathrm{BPB}$. The results obtained and shown in (Tables 2 and 3) were compared to those obtained by a reference method [14] by means of $t$-test at $95 \%$ confidence level. In all cases, the average results obtained by proposed methods and reference method were statistically identical, as the difference between average values had no significance at $95 \%$ confidence level.

The proposed methods are simple, sensitive, and reproducible and can be used for routine analysis of tenofovir in pure form and in formulation.

\section{Conflict of Interests}

The authors declare that there is no conflict of interests regarding the publication of this paper.

\section{Acknowledgments}

The authors are thankful to the Principal and Head, Department of Chemistry, Nizam College, and to the authorities of Jawaharlal Nehru Technology University, Hyderabad, for providing laboratory facilities.

\section{References}

[1] M. D. Miller, N. Margot, B. Lu et al., "Genotypic and phenotypic predictors of the magnitude of response to tenofovir disoproxil fumarate treatment in antiretroviral-experienced patients," Journal of Infectious Diseases, vol. 189, no. 5, pp. 837846, 2004.
[2] J. E. Gallant, E. Dejesus, J. R. Arribas et al., "Tenofovir DF, emtricitabine, and efavirenz vs. zidovudine, lamivudine, and efavirenz for HIV," The New England Journal of Medicine, vol. 354, no. 3, pp. 251-260, 2006.

[3] Viread (Tenofovir) a Product Monograph, Gilead Sciences, Foster City, Calif, USA, 2001.

[4] T. King, L. Bushman, J. Kiser et al., "Liquid chromatographytandem mass spectrometric determination of tenofovirdiphosphate in human peripheral blood mononuclear cells," Journal of Chromatography B: Analytical Technologies in the Biomedical and Life Sciences, vol. 843, no. 2, pp. 147-156, 2006.

[5] T. Delahunty, L. Bushman, and C. V. Fletcher, "Sensitive assay for determining plasma tenofovir concentrations by LC/MS/MS," Journal of Chromatography B: Analytical Technologies in the Biomedical and Life Sciences, vol. 830, no. 1, pp. 6-12, 2006.

[6] N. L. Rezk, R. D. Crutchley, and A. D. M. Kashuba, "Simultaneous quantification of emtricitabine and tenofovir in human plasma using high-performance liquid chromatography after solid phase extraction," Journal of Chromatography B: Analytical Technologies in the Biomedical and Life Sciences, vol. 822, no. 1-2, pp. 201-208, 2005.

[7] S. Sentenac, C. Fernandez, A. Thuillier, P. Lechat, and G. Aymard, "Sensitive determination of tenofovir in human plasma samples using reversed-phase liquid chromatography," Journal of Chromatography B: Analytical Technologies in the Biomedical and Life Sciences, vol. 793, no. 2, pp. 317-324, 2003.

[8] N. A. Raju and S. Begum, "Simultaneous RP-HPLC method for the estimation of Emtricitabine, Tenofovir and Efavirenz in tablet dosage forms," Research Journal of Pharmacy and Technology, vol. 1, no. 4, pp. 522-525, 2008.

[9] E. Rey, G. Pons, J. Treluyer, and V. Julien, "Determination of Tenofovir in Human plasma by HPLC with spectroflourimetric detection," Journal of Chromatography B, vol. 785, no. 2, pp. 377381, 2003.

[10] M. Joshi, A. P. Nikalje, M. Shahed, and M. Dehghan, "HPTLC method for the simultaneous estimation of emtricitabine and tenofovir in tablet dosage form," Indian Journal of Pharmaceutical Sciences, vol. 71, no. 1, pp. 95-97, 2009.

[11] R. W. Sparidans, K. M. L. Crommentuyn, J. H. M. Schellens, and J. H. Beijnen, "Liquid chromatographic assay for the antiviral nucleotide analogue tenofovir in plasma using derivatization with chloroacetaldehyde," Journal of Chromatography B: Analytical Technologies in the Biomedical and Life Sciences, vol. 791, no. 1-2, pp. 227-233, 2003.

[12] M. E. Barkil, M.-C. Gagnieu, and J. Guitton, "Relevance of a combined UV and single mass spectrometry detection for the determination of tenofovir in human plasma by HPLC in therapeutic drug monitoring," Journal of Chromatography B: Analytical Technologies in the Biomedical and Life Sciences, vol. 854, no. 1-2, pp. 192-197, 2007.

[13] A. Shirkhedkar Atul, H. Bhirud Charushila, and J. Surana Sanjay, "Application of UV-spectrophotometric methods for estimation of tenofovir disoproxil fumarate in tablets," Pakistan Journal of Pharmaceutical Sciences, vol. 22, no. 1, pp. 27-29, 2009.

[14] V. P. Choudari, S. Ingale, S. R. Gite, D. D. Tajane, V. G. Modak, and A. Ambekar, "Spectrophotometric simultaneous determination of Tenofovir disoproxil fumarate and emtricitabine in combined form by ratio derivative, first order derivative and absorbance corrected method and its application to dissolution study," Pharmaceutical Methods, vol. 2, pp. 47-52, 2011. 
[15] J. O. Onah and U. Ajima, "Spectrophotometric determination of tenofovir disoproxil fumarate after complexation with ammonium molybdate and picric acid," International Journal of Drug Development and Research, vol. 3, no. 1, pp. 199-204, 2011.

[16] H. T. S. Britton, Hydrogen Ions, vol. 1, Chapman and Hall, London, UK, 1942.

[17] W. C. Vosburgh and G. R. Coopper, "The identification of complex ions in solution spectrometric measurements," Journal of the American Chemical Society, vol. 63, no. 437, 1941.

[18] W. Likussar and D. F. Boltz, "Theory of continuous variations plots and a new method for spectrophotometric determination of extraction and formation constants," Analytical Chemistry, vol. 43, no. 10, pp. 1265-1272, 1971.

[19] K. Momoki, J. Sekino, H. Sato, and N. Yamaguchi, "Theory of curved molar ratio plots and a new linear plotting method," Analytical Chemistry, vol. 41, no. 10, pp. 1286-1299, 1969.

[20] "International Conference on Harmonization (ICH) of Technical Requirement for the Registration of Pharmaceuticals for Human use, Validation of Analytical procedures definitions and Terminology Genera," 1996. 

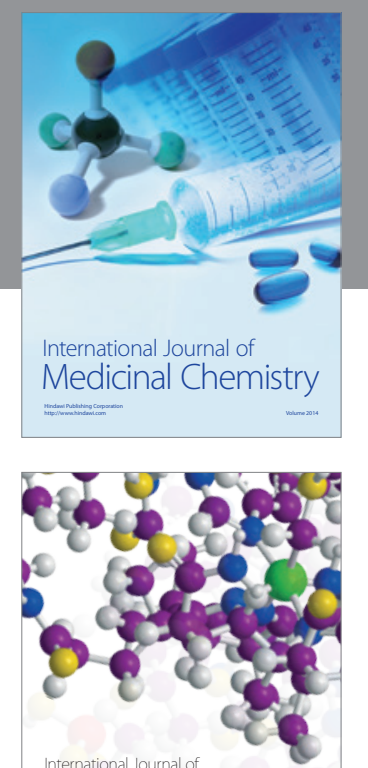

\section{Carbohydrate} Chemistry

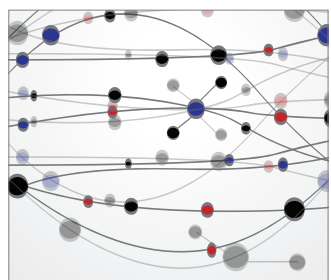

The Scientific World Journal
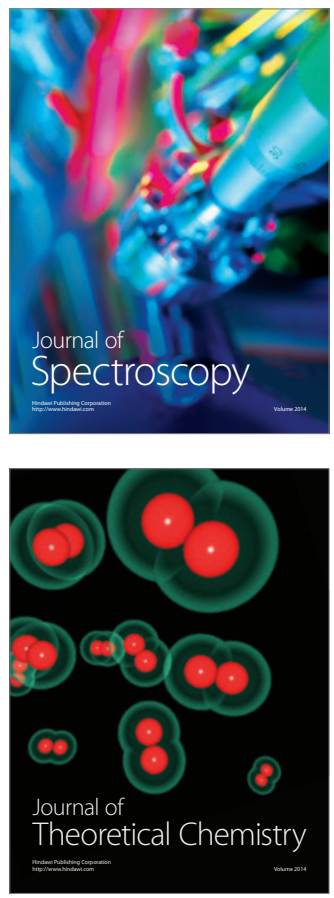
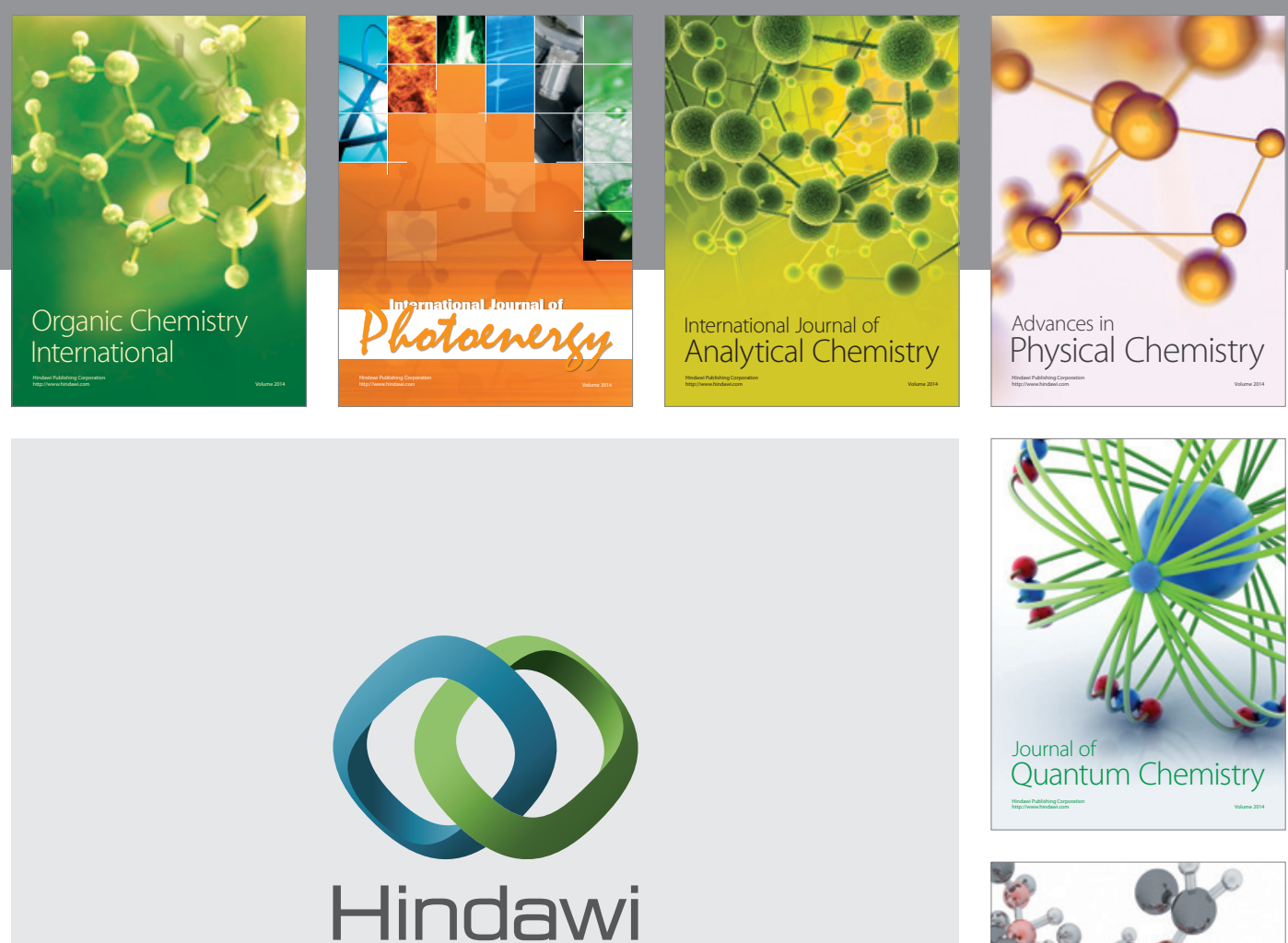

Submit your manuscripts at

http://www.hindawi.com

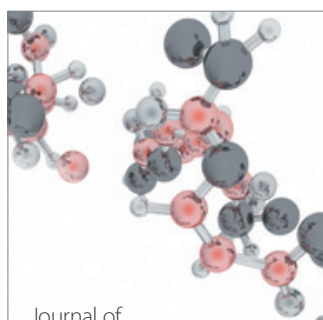

Analytical Methods

in Chemistry

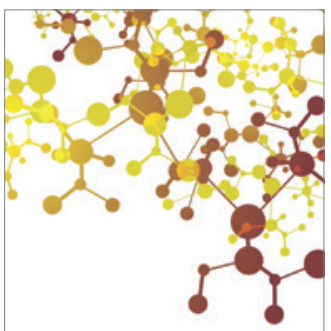

Journal of

Applied Chemistry

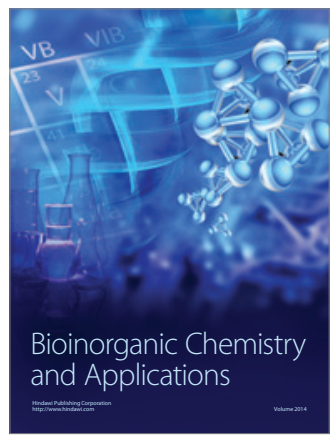

Inorganic Chemistry
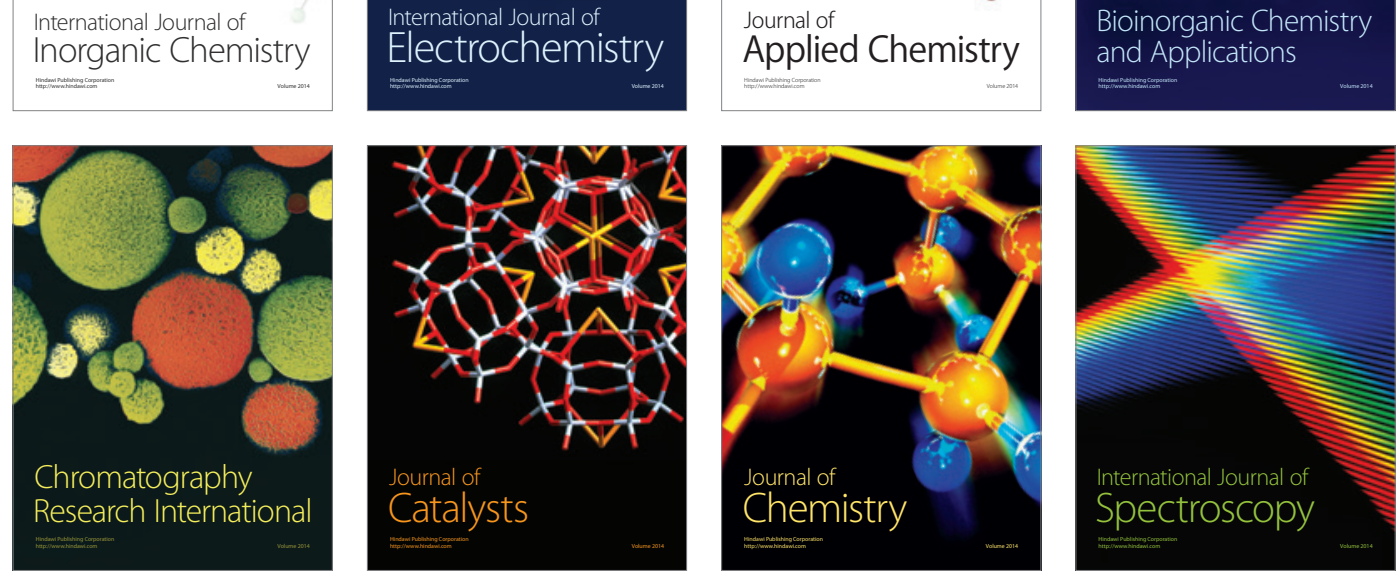